\title{
O CURSO DE EXTENSÃO EM EXTENSÃO RURAL À LICENCIATURA EM EDUCAÇÃO DO CAMPO NA UFRRJ
}

\author{
Jaime Rodrigo da Silva ${ }^{1}$
}

DOI: https://doi.org/10.31692/978-65-991061-7-0.461-464

\section{INTRODUÇÃO}

Este trabalho apresenta uma iniciativa em andamento há dois semestres na UFRRJ, que consiste na oferta do Curso de Extensão em Extensão Rural a estudantes da Licenciatura em Educação do Campo (LEC) desta instituição. A motivação da proposta parte da ausência de disciplina(s) obrigatória(s) ou optativa(s) que trate especificamente da temática Extensão Rural na matriz curricular da LEC, o que, na visão do autor deste relato e mentor do projeto, representa uma grave lacuna formativa a ser preenchida.

Considera-se que o processo de institucionalização dos cursos regulares destas Licenciaturas através do Programa Nacional de Educação do Campo (PRONACAMPO, de 2010) e o processo de institucionalização da Política Nacional de Assistência Técnica e Extensão Rural (PNATER, de 2004) se orientam por princípios e objetivos bastante convergentes, principalmente no tocante à participação de representantes das populações do campo na sua construção e ao fortalecimento destes segmentos historicamente negligenciados nas agendas de desenvolvimento do país. Assim, diante de limitações que impedem debates interdisciplinares visando inclusão de ao menos uma disciplina obrigatória sobre ATER na grade, a experiência aqui relatada se torna, em certa medida, uma possibilidade de cobertura desta lacuna. O objetivo geral é garantir que os/as futuros Educadores(as) do Campo conheçam a proximidade entre sua área de atuação e a prática extensionista, sendo ambos instrumentos educacionais para garantia de transformações sociais no campo.

\section{RELATO DE EXPERIÊNCIA}

A criação do curso de LEC na UFRRJ ocorreu em 2010, por meio de edital PRONERA/2009 em parceria com movimentos sociais e sindicais do campo e representação de povos tradicionais (UFRRJ, 2018). Sua institucionalização ocorre em 2013, via edital do MEC/2012 que possibilitou a oferta regular em várias universidades.

No Projeto Político Pedagógico (PPP), dentre toda as disciplinas de 60 horas, de 30 horas e atividades acadêmicas contidas em 2 eixos (eixo Ciências Sociais e Humanidades; eixo Pedagógico, Agroecologia e Diversidade) não há nenhuma que contemple, especificamente, Extensão Rural. O tema está presente em uma única obrigatória do primeiro 
eixo intitulada Ideologia do Moderno no Campo, sob a forma de um ítem da ementa assim descrito: “... a Extensão Rural e outros 'processos modernizantes”” (UFFRRJ, 2018, p.26. Grifo do autor).

Diante desta ausência de conteúdo, o autor deste relato - tendo sido Extensionista por cinco anos em áreas de reforma agrária na Amazônia e há nove professor desta área - vem oferecendo semestralmente um Curso de Extensão para tratar especificamente do assunto, que pode ser abordado sob distintos focos, dentre eles: como área acadêmica em disciplina obrigatória nas Ciências Agrárias e área de formação scrictu sensu nível de Mestrado e Doutorado; como área de atuação a profissionais de várias áreas, oriundos principalmente das Ciências Agrárias e C. Humanas; como um direito assegurado a trabalhadores rurais no texto de nossa Constituição; como uma política pública federal, cujos princípios e objetivos são bastante similares aos apontados no PRONACAMPO.

Enfocando a ação extensionista em vigor no país através da PNATER, o curso aborda o histórico da política governamental ao longo dos últimos 70 anos, trazendo aos/as licenciandos as principais concepções que orientaram as práticas do passado e como tais concepções se diferem da "Nova Extensão Rural'. Esta, instituída em 2004, apresenta como princípios o fortalecimento sócio-político e econômico da Agricultura Familiar, a garantia de direitos sociais no campo com sustentabilidade ambiental, tendo-se na Agroecologia o eixo de orientação das intervenções com uso de metodologias participativas e valorização dos saberes tradicionais, visando a permanência dos sujeitos do campo com qualidade de vida e protagonismo na construção dos caminhos de seus desenvolvimento e de sua história, garantindo segurança alimentar e nutricional à sociedade.

Esta proposta teórico-metodológica de fim educativo se alinha às propostas da LEC, fazendo com que um/a Extensionista Rural e um/a Educador do Campo sejam profissionais comprometidos com os mesmos objetivos e mesmo público. Conforme Molina (2014), a Educação do Campo "germina, nasce e frutifica na/da luta pela terra, pelos direitos a uma vida digna, pela relação igualitária entre homens e mulheres, pela distribuição igualitária da renda e dos bens produzidos pela sociedade de forma justa.” (p. 225). As Licenciaturas assumem neste contexto papel de formadoras de um educador que, para além da educação escolar, atue como agente de transformação da realidade social na gestão de processos educativos escolares e não-escolares, afirmando o lugar do campo no projeto de desenvolvimento nacional diante dos desafios impostos aos camponeses para se manterem em seus territórios pelo avanço do agronegócio. (MOLINA, 2014. Grifo meu.)

No PPP da LEC da UFRRJ, um dos objetivos específicos é formar profissionais que 
desenvolvam estratégias pedagógicas visando a "formação de sujeitos humanos autônomos e criativos, capazes de produzir soluções para questões inerentes à sua realidade, vinculadas à construção de um projeto de desenvolvimento sustentável de campo e de país." (UFRRJ, 2018, p.8)

São notórias as afinidades políticas entre a PNATER e a área Educação do Campo que podem resultar em parcerias na atuação junto às populações, mas que se tornam desconhecidas dos/as futuros Licenciados devido à ausência deste debate na composição da matriz. São duas forças políticas que pouco dialogam academicamente - e por vezes, também no campo - reduzindo-se o potencial de transformação em conjunto.

O curso de 20 horas foi iniciado em março de 2018, com 14 inscritos. Na segunda versão realizada entre 10 e 21 de setembro, houve 37 inscritos. Há divulgação pela secretaria de graduação, exigindo-se do/a interessado nome, matrícula e período (o/a estudante há mais tempo no curso tem prioridade caso haja mais interessados do que a capacidade do espaço físico utilizado). É composto de dez aulas de duas horas diárias divididas em uma unidade teórica e outra "prática". A primeira aborda politicamente a Extensão como instrumento do Estado - a partir do pós-segunda Guerra - impulsionador do projeto de modernização agrícola e seus impactos, até o surgimento da "Nova Extensão Rural" no início dos anos 2000. Na segunda, traz-se a PNATER, sua nova concepção, limites, potencialidades e a experiência prática do professor e de outros/as extensionistas através de fotografias, vídeos e debates a cerca de situações cotidianas encontradas junto a agricultores/as e comunidades. São imagens dos trabalhos de Extensão Rural nas seguintes dimensões: Técnico-econômicas (criações animais, cultivos vegetais, atividades não agrícolas, créditos do PRONAF, desafios de produção, mercado, geração de renda, etc); Agroecológicas e Ambientais (desafios à adoção de princípios agroecológicos nas intervenções, educação ambiental, reflorestamento e recuperação, desafios diante de leis ambientais, etc); Sócio-culturais (ações junto a escolas e acesso a educação, saúde, estradas, energia elétrica e infra-estrutura básica nas comunidades, questões de gênero, étnicas, etc); Políticas e Organizativas (associativismo, cooperativismo, sindicalismo, movimentos sociais, mediação com órgãos públicos, etc). Pelos debates provocados através das imagens e vídeos, busca-se ao final problematizar a distância entre Extensionistas e Educadores/as do Campo, considerando que os últimos, partindo das escolas, devem construir processos de transformação da realidade rural, assim como os agentes de ATER em suas várias atribuições. Enfatizando-se que "a busca da inclusão social da população rural brasileira mais pobre será elemento central de todas as ações orientadas pela Política Nacional de Ater" (BRASIL, 2004, p. 4), o curso traz à tona a necessária 
aproximação entre duas áreas potencialmente transformadoras.

\section{CONSIDERAÇÕES}

Esta iniciativa tem possibilitado aos/as estudantes pensar Extensão Rural como um direito do/a agricultor familiar brasileiro atualmente oferecido via política pública que, mesmo em séria crise de operacionalidade, deve ser instrumento de marcantes mudanças sociais assim como o PRONACAMPO. Nesse sentido, conforme impressões das turmas ao final do processo de formação, tem-se reconhecido a relevância do tema para a/o futuro Licenciado e a necessária interação entre as duas áreas, gerando-se maior interesse pela temática não apenas no âmbito acadêmico, mas em presentes e futuras ações no campo visando o fortalecimento das populações rurais num momento político a elas tão desfavorável.

\section{REFERÊNCIAS}

BRASIL. Ministério do Desenvolvimento Agrário. Secretaria de Agricultura Familiar. Departamento de Assistência Técnica e Extensão Rural. Política Nacional de Assistência Técnica e Extensão Rural. Brasília, 2004.

MOLINA, M.C. Educação do Campo: história, práticas e desafios no âmbito das políticas de formação de educadores - reflexões sobre o PRONERA e o PROCAMPO. Revista Reflexão e Ação: Santa Cruz do Sul, v.22, n.2, p.220-253, jul./dez.2014. Disponível em <http://online.unisc.br/seer/index.php/reflex/index >. Acesso em 12 de setembro de 2018.

Projeto Político-Pedagógico do Curso de Licenciatura em Educação do Campo. Disponível em <www.ufrrj.br/soc/DOCS/deliberacoes_2010/Delib082CEPE2010.pdf> Acesso em 10 de setembro de 2018. 